\title{
Multivariate Regression Analysis Of The Physical Conditions Of Athletic Archeries In Pre Pon West Kalimantan
}

\author{
Is ti Dwi Puspita Wati' ${ }^{1)}$ A'yunin Sofro ${ }^{2)}$ \\ Ilmu Keolahragan, \\ ${ }^{1,2}$ Universitas Negeri Surabaya, Indonesia \\ Email : ${ }^{1}$ isti.21003@mhs.unesa.ac.id ${ }^{2}$ ayuninsofro@unesa.ac.id
}

\begin{abstract}
For athlete's physical condition is one of the things that must be considered. One of them is the $\mathrm{VO}_{2}$ maks capacity. $\mathrm{VO}_{2}$ maks capacity is the body's ability to enter as much oxygen as possible into the lungs. The oxygen that managed to enter will then be distributed throughout the body to sufficient. Apart from the 02 carrying capacity, an archery athlete also needs flexibility. Flexibility must be possessed to prevent injury. This study aimed to explore and determine the effect of HB and BMI levels on the VO2 maks capacity and flexibility of athletes. This research is descriptive correlational research. The sample is archery athletes as many as 24 athletes. The measurement of VO2maks was carried out using the bleep test and $\mathrm{HB}$ with the Hb test, while flexibility was carried out using the sit and reach test and BMI by measuring the athlete's height and weight. Based on the $r$ multivariate multiple regression analysis, it can be concluded that the levels of $\mathrm{HB}$ and BMI do not significantly affect the VO2 maks capacity and flexibility of athletes. Significantfigures of 0.2583 and 0.2328 indicate this.
\end{abstract}

Keywords: VO2maks, Flexibility, Multivariate Multiple Regression

\section{Analisis Regresi Multivariate Kondisi Fisik Atlet Panahan Pra Pon Kalimantan Barat}

\begin{abstract}
ABSTRAK
Kondisi fisik atlet menjadi salah satu hal yang hans diperhatikan. Salah satunya adalah kapasitas $\mathrm{VO}_{2}$ maks. Kapasistas $\mathrm{VO}_{2}$ maks merupakan kemampuan tubuh dalam memasukkan oksigen sebanyak-banyaknya kedalam pan-pan. Oksigen yang berhasil masuk kemudian akan didistribusikan ke seluruh tubuh agar penyediaan energy tercukupi. Selain dari kapasitas pengangkutan $\mathrm{O}_{2}$ maka seorang atlet panahan juga memerlukan kelenturan. Kelenturan tersebut hanus dimiliki untuk mencegah terjadinya cidera. Tujuan penelitian ini adalah untuk menggali dan mengetahui penganuh kadar $\mathrm{HB}$ dan $\mathrm{BMI}$ terhadap kapasitas $\mathrm{VO}_{2}$ maks dan kelenturan atlet. Penelitian ini merupakan penelitian deskriptif korelasional. Sampel adalah atlet cabang olahraga panahan sebanyak 24 atlet. Pengukuran $\mathrm{VO}_{2}$ maks dilakukan dengan tes Bleep test dan $\mathrm{HB}$ dengan $\mathrm{Tes} \mathrm{Hb}$, sedangkan kelenturan dilakukan dengan menggunakan sit and reach tes dan BMI dengan mengukur tinggi badan dan berat badan atlet. Berdasarkan hasil analis is multivariate multiple regresi maka dapat di simpulkan bahwa kadar HB dan BMI tidak terlalu berpengaruh pada kapasitas VO2 maks dan kelenturan atlet. Hal ini ditunjukkan dengan angka signifikasi sebesar 0.2583 dan 0.2328
\end{abstract}

Kata Kunci: VO2maks, Kelenturan, Multivariate Multiple Regresi

Info Artikel

Dikirim $\quad: 16$ Oktober 2021

Diterima : 20 November 2021

Dipublikasikan : 30 November 2021
(C) 2021 IKIP BUDI UTOMOMALANG

P-ISSN 2613-9421

E-ISSN 2654-8003

\footnotetext{
Alamat korespondensi: isti.21003@mhs.unesa.ac.id,

Universitas Negeri Surabaya, Jl. Lidah Wetan, Lidah Wetan, Kec. Lakarsantri, Kota SBY, Jawa Timur 60213, Indonesia
} 
Isti Dwi Puspita Wati ${ }^{1)}$, A'yunin Sofro ${ }^{2}{ }^{\text {}}$.Jp.jok (Jurnal Pendidikan. Jasmani, Olahraga dan Kesehatan). 5(1)

\section{PENDAHULUAN}

Kondisi fisik atlet merupakan senjata utama dalam mengikuti setiap event olahraga yang digeluti. Karena dengan memiliki kondisi fisik yang bagus maka atlet akan mampu menampilkan performance yang maksimal. Kondisi fisik yang dimaksud disini adalah kemampuan biomotor seseorang. Adapun kemampuan biomotor antara lain adalah kekuatan, power, daya tahan otot, daya tahan kardiovaskuler, kelenturan, dan koordinasi mata tangan mata kaki. Dari berbaga i komponen biomotor tersebut maka dpat dipastikan bahwa atlet memiliki kondisi yang prima.

Persiapan dalam mengikuti event dalam skala nasional, semua atlet berusaha untuk memberikan penampilan terbaik. Untuk dapat berkompetisi dalam ajang PON maka atlet harus lolos seleksi dalam ajang PRA PON terlebih dahulu. Olahr karena itu provinsi Kalimantan Barat berupaya untuk menyeleksi atlet-atlet terbaik untuk dapat berkompetisi dalam ajang PRA PON.

Cabang olahraga panahan merupakan salah satu cabang olahraga yang ikut serta dalam event Pra PON. Oleh karena itu, provinsi Kalimantan Barat melakukan seleksi untuk para atlet terbaik. Salah satu yang dilakukan oleh KONI provinsi adalah memberikan tes kesehatan dan kondisi fisik atlet. Guna mendapatkan informasi yang nyata mengenai keadaan atlet panahan.

Dalam cabang olahraga panahan, kemampuan $\mathrm{VO}_{2}$ maks merupakan kunci utama dalam kesuksesan dalam ketepatan memanah target. Selain itu keadaan $\mathrm{VO}_{2}$ maks merupakan indikator keadaan fisik seseorang. Seperti yang dikatakan dalam penelitian yang dilakukan oleh (Fernström et al., 2017) bahwa $\mathrm{VO}_{2}$ maks berhubungan dengan rendahnya kemungkinan menderita penyakit kardiovaskuler.

(Kuncoro et al., 2020) Atlet yang memiliki $\mathrm{VO}_{2}$ maks rendah tidak akan mampu bekerja secara maksimal. Asumsi bahwa orang yang memiliki $\mathrm{VO}_{2}$ maks yang baik maka pada saat melakukan olahraga tidak akan mengalami kelelahan dengan cepat. Oleh karena itu memiliki $\mathrm{VO}_{2}$ maks yang tinggi sangat menguntungkan bagi atlet. Kapasitas $\mathrm{VO}_{2}$ maks setiap orang berbeda-beda. Hal ini tidak dengan serta merta diperoleh dengan mudah. Diperlukan latihan yang teratur dalam jangka yang lama. Sedangkan adaptasi latihan dengan adaptasi peningkatan $\mathrm{VO}_{2}$ maks setiap individu tidak sama (Joyner \& Lundby, 2018). 
Pada prinsipnya $\mathrm{VO}_{2}$ maks dipergunakan untuk meningkatkan kemampuan memasukkan $\mathrm{O}_{2}$. Selanjutnya tugas ini kemudian diambil alih oleh $\mathrm{HB}$. $\mathrm{HB}$ menjalankan fungsinya sebagai pembawa oksigen dalam darah. JIka terjadi anemia maka jumlah HB dalam darah untuk putra dan putri dibawah 13 dan 12, hal ini akan berimbas pada penurunan fungsi aerobic (Baron et al., 2014); Musallam et al., 2011). Banyak faktor ternyata yang mempengaruhi jumlah HB dalam darah, diantarnya, ketinggian tempat tinggal, intensitas dan durasi latihan, genetic, asupan zat besi, serta riwayat penyakit Berdasarkan penelitian diketahui kadar $\mathrm{HB}$ dapat dilihat dari kemampuan $\mathrm{VO}_{2}$ maks (daya tahan) (Jacobs et al., 2011).

Pemanah juga memerlukan kelenturan selain kapasitas $\mathrm{VO}_{2}$ maks. ke lenturan persendian memungkinkan atlet untuk tetap terjaga dan terbebas dari cidera. Sedangkan kelenturan sendiri dapat dipengaruhi oleh keberadaan lemak dalam tubuh. Meskipun kelenturan tergantung dari range of movement (ROM) dari persendian namun dengan adanya lemak yang banyak akan membuat gangguan dalam kelenturan tersebut. Banyaknya lemak dalam tubuh tentunya akan berdampak pada indek masa tubuh (BMI) atlet. Tujuan dari pe nelitian ini adalah untuk membuktikan apakah faktor kadar $\mathrm{Hb}$ dan $\mathrm{BMI}$ berpengaruh secara bersama-sama terhadap kapasitas $\mathrm{VO}_{2}$ maks dan kelenturan atlet panahan. Alasan utama peneliti mengangkat permasalahan ini adalah karena selama ini hanya belum pernah dilakukan analisis secara serentak faktor-faktor tersebut secara bersama-sama dengan kapasitas $\mathrm{VO}_{2}$ maks dan kelenturan yang diperlukan oleh atlet panahan.

\section{METODE}

Penelitian ini merupakan penelitian deskriptif. Peneltiian deskriptif adalah penelitian yang bermaksud untuk menggambarkan dan memaparkan suatu keadaan dilapangan apa adanya (Sugiyono, 2017). Objek penelitian dalam penelitian ini adalah atlet Kalimantan Barat cabang olahraga panahan. Sampel yang dipilih adalah atlet panahan yang menjadi juara dalam ajang pekan olahraga propinsi (Porprov) dan kejurnas panahan dengan jumlah 24 orang. Variabel 
Isti Dwi Puspita Wati ${ }^{1)}$, A'yunin Sofro ${ }^{2}{ }^{\text {}}$.Jp.jok (Jurnal Pendidikan. Jasmani, Olahraga dan Kesehatan). 5(1)

independen dan dependen yang diangkat dalam penelitian ini adalah Kadar $\mathrm{Hb}$ dan BMI serta kapasitas $\mathrm{VO}_{2}$ maks dan kelenturan.

Variabel dependen adalah variabel yang nilainya dipengaruhi oleh variabel bebas, yang menjadi variabel dependen dalam penelitian ini adalah kapasitas VO2maks dan kelenturan dimana defenisi operasional variabelnya adalah sebagai berikut : Kapasitas $\mathrm{VO}_{2}$ maks adalah jumlah volume oksigen maksimal (dalam mililiter) yang dapat dimaksukkan ke dalam paru-paru per menit per kilogram berat badan, hal ini diukur dengan menggunakan tes multi stage (bleep tes). Sedangkan kelenturan adalah kemampuan tubuh untuk melakukan gerak melalui ruang gerak sendi atau ruang gerak tubuh secara maksimal, yang diukur dengan tes flexlibility sit and reach.

Adapun variable independen dalam pene litian ini adalah Kadar Hb dan BMI, adapun definisi operasionalnya adalah sebagai berikut: Kadar $\mathrm{Hb}$ adalah jumlah zat pembawa oksigen dalam darah yang dapat diukur secara kimia dengan mengukur $\mathrm{Hb}$ / tes $\mathrm{Hb}$. BMI adalah besaran ukuran untuk menilai kesesuaian berat badan dan tinggi badan seseorang, dengan mengukur tinggi badan dan berat badan atlet.

Data dikumpulkan dengan menggunakan tes dan pengukuran. Adapun tes yang dilakukan adalah bleep tes, sit and reach tes. Pelaksanaan tes dilakukan secara prosedural mengikuti petunjuk dari (Brian Mackenzie, 2005). Analisis data yang digunakan dalam penelitian ini adalah analis is multivariate multiple regresi karena memilki 2 variabel dependen dan 2 variabel indipenden (Johnson dan Wichern, 2007).

\section{HASIL DAN PEMBAHASAN}

Hasil dari penelitian ini adalah menunjukkan karakteristik dari beberapa variable yang diduga memiliki pengaruh terhadap kapasitas VO2maks dan kelenturan dari atlet panahan propinsi Kalimantan Barat. Berikut adalah karakteristik sampel yang digunakan dalam penelitian ini. Dapat dilihat pada tabel 1 : 
214 Isti Dwi Puspita Wati ${ }^{1)}$, A'yunin Sofro ${ }^{2}{ }^{\text {. }}$.Jp.jok (Jurnal Pendidikan. Jasmani, Olahraga dan Kesehatan). 5(1)

Tabel 1. Karakteristik Data Variabel Respon dan Variabel Prediktor

\begin{tabular}{lrrrlrr}
\hline & \multicolumn{3}{c}{ Maksimu } & \multicolumn{2}{c}{ Std. } \\
& $\mathrm{N}$ & Minimum & $\mathrm{m}$ & Mean & Deviation & Variance \\
\hline HB $\left(\mathrm{X}_{1}\right)$ & 24 & 11.00 & 18.50 & 13.9917 & 1.61270 & 2.601 \\
BMI $\left(\mathrm{X}_{2}\right)$ & 24 & 17.30 & 34.00 & 23.2583 & 4.52797 & 20.503 \\
VO2maks $\left(\mathrm{Y}_{1}\right)$ & 24 & 21.60 & 44.90 & 29.6500 & 5.80951 & 33.750 \\
Kelenturan $\left(\mathrm{Y}_{2}\right)$ & 24 & 6.50 & 23.00 & 16.2000 & 5.31847 & 28.286 \\
\hline
\end{tabular}

Rata-rata kadar $\mathrm{Hb}$ atlet panahan Kalimantan Barat adalah 13,99 dengan kadar minimum 11 dan maksimal 18,50. Dilihat dari kadar HB tersebut maka dapat dikatakan bahwa atlet panahan Kalimantan Barat dapat dikatakan memiliki kadar Hb normal sesuai dengan anjuran dari WHO dan memiliki standar deviasi sebesar 1,613. Rata-rata BMI dari atlet panahan sebesar 23,26, dengan nilai BMI minimal sebesar 17,30 dan maksimal 34, sehingga dapat dikatakan bahwa altlet panahan memiliki postur tubuh yang ideal meskipun ada yang memiliki postur tubuh yang kurus da nada yang mengalami kegemukan. Kapasitas rata-rata VO2maks atlet panahan Kalimantan Barat sebesar 29,65 dan kelenturan sebesar 16,2. Hal ini menunjukkan bahwa atlet panahan Kalimantan Barat memiliki kapasitas VO2maks yang buruk meskipun memiliki kelenturan yang baik.

\section{Pemodelan Faktor-Faktor yang Berpengaruh Terhadap Kapasitas $\mathrm{VO}_{2}$ maks dan Kelenturan}

Pemodelan faktor-faktor yang mempengaruhi kapasitas VO2maks dan kelenturan menggunakan metode analisis regresi multivariate karena memiliki 2 variabel terikat (dependen) yaitu VO2maks dan kelentukan. Selain memiliki 2 variabel dependen, penelitian ini memiliki 2 variabel independen yang meliputi kadar $\mathrm{Hb}$ dan BMI. Guna melihat hubungan antar variabel maka dapt dilihat dalam scatterplot pada gambar 1 .. Scatterplot tersebut dapat digunakan untuk melihat besar korelasi antar variabel. 

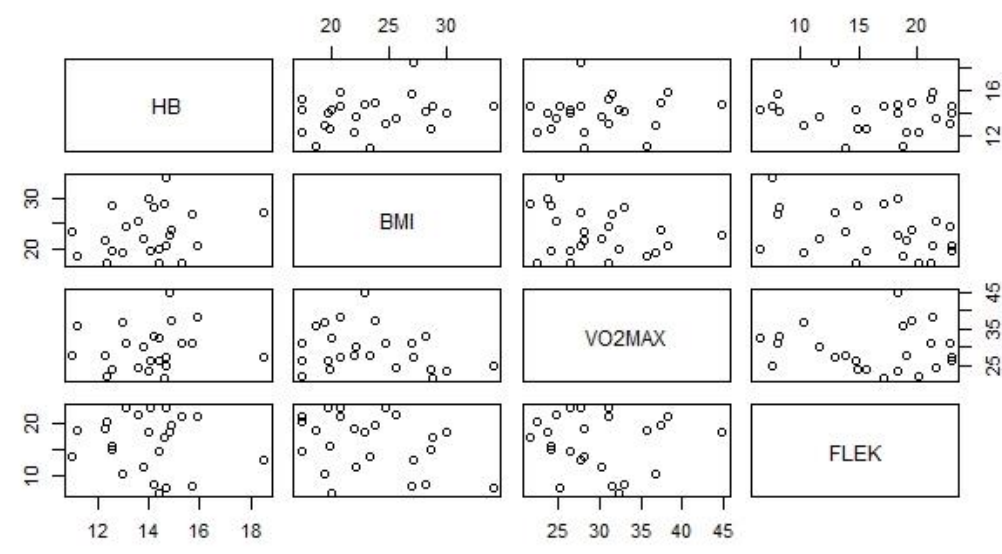

BMI
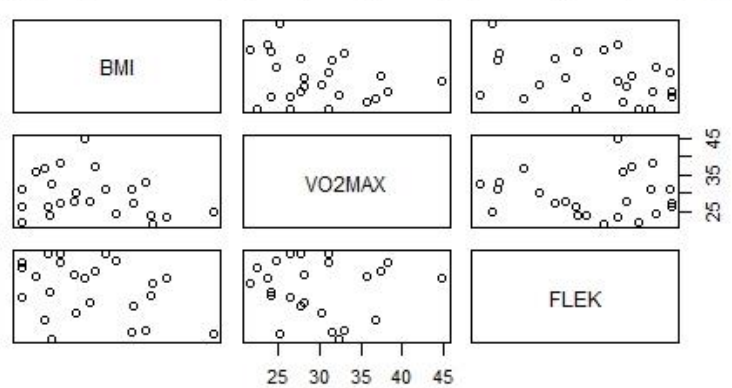

Gambar1. Scatterplot Antar Variable Dependen Dan Independen

Guna mengetahui pengaruh variable-varibel yang dipilih dalam penelitian ini maka ditampilkan dalam bentuk persamaan regresi menjadi $Y_{1}=\beta_{0}+\beta_{1} X_{1}+$ $\beta_{2} X_{2}+\beta_{3} X_{3}$ dan seterusnya. Melalui persaman ini maka dapat diketahui pengaruh antar variabel bebas terhadap variabel terikat. Estimasi persamaan model terhadap variabel $\mathrm{VO}_{2}$ maks adalah $\mathrm{Y}_{1}=-347,44-9,2 \mathrm{X}_{1}-0,17 \mathrm{X}_{2}$. Sedangkan persamaan fungsi regresi terhadap variabel kelenturan ada lah $Y_{2}=304$ $+1,43 X_{1}-0,17 X_{2 . .}$ Artiya, bahwa jika $X_{1}$ dan $X_{2}=0$ maka $Y_{1}{ }^{\prime}=-347,44$ dan jika $X_{1}$ naik 1 poin dan $X_{2}=0$ maka $Y_{1}$ ' akan naik turun sebesar -356,64. Selain itu berdasarkan persamaan kedua maka jika $X_{1}$ dan $X_{2}=0$ maka $Y_{1}{ }^{\prime}=$ 304 dan jika $X_{1}$ naik 1 poin dan $X_{2}=0$ maka $Y_{1}^{\prime}$ akan naik naik sebesar 447 .

Pada persamaan regresi pertama besar nilai konstanta sebesar -347,44 pada persamaan regresi di atas menunjukkan bahwa kapasitas VO2maks atlet sebesar 347,44 tanpa terpengaruh dari variabel bebas lainnya. Apabila terjadi peningkatan kadar HB 1 satuan saja, maka akan menambah kapasitas $\mathrm{VO}_{2}$ maks sebesar 9,2 satuan. Bila variabel BMI meningkat sebesar 1 satuan, maka kapasitas $\mathrm{VO}_{2}$ maks akan bertambah sebesar 0,17 . Sedangkan pada persamaan regresi kedua besar nilai konstanta sebesar 304 pada persamaan regresi di atas menunjukkan bahwa kapasitas $\mathrm{VO}_{2}$ maks atlet sebesar 304 tanpa adanya pengaruh dari variabel-variabel bebas. Bila variabel kadar HB meningkat sebesar 1 satuan, maka kapasitas $\mathrm{VO}_{2}$ maks akan bertambah sebesar 1,43. Bila variabel BMI meningkat sebesar 1 satuan, maka kapasitas VO2maks akan bertambah sebesar 0,17 . 
HB berwarna merah merupakan warna alami dari darah di dalamnya terdapat kandungan zat besi yang berfungsi untuk mengikat $\mathrm{O}_{2}$ dan $\mathrm{CO}_{2}$ (Sherwood, 2011:424). Logika positifnya adalah bahwa akan saling berkaitan erat antara HB dengan $\mathrm{VO}_{2}$ maks (Schimdt dan Prommer, 2010). Akan diperoleh keuntungan besar jika $\mathrm{HB}$ dan $\mathrm{VO}_{2}$ maks tinggi. Ada bukti bahwa atlet yang hb-nya tinggi memiliki daya tahan yang bagus (Goodrich et al., 2018) (Aryaputra et al., 2020) (Malczewska-Lenczowska et al., 2016).

Yang menjadi permasalahan adalah bagaimana meningkatkan HB dengan cara olahraga penelitian terdahulu belum mememehuni kesepakatan di satu pihak dengan latihan di dataran tinggi (Neya et al., 2012) dan (Wehrlin et al., 2016) dengan latihan hipoxia dapat meningkatkan HB, tetapi dilain pihak tidak terjadi perubahan HB (Du Bois et al., 2014).

Berdasarkan hasil perhitungan koefisien determinasi maka diperoleh harga $\mathrm{r}_{1}{ }^{2}$ $=-0,36189$ dan $r_{2}^{2}=-0,00033$. Artinya bahwa kadar HB dan BMI atlet panahan mempengaruhi banyaknya kapasitas $\mathrm{VO}_{2}$ maks sebesar $36,189 \%$ dan sisanya dipengaruhi oleh variable lain. Kadar HB dan BMI atlet panahan mempengaruhi kelenturan sebesar 0,033\% dan sisanya dipengaruhi oleh variable lain.

Berdasarkan hasil analisis regresi multivariat menunjukkan bahwa kapasitas $\mathrm{VO}_{2}$ maks dan kelenturan tidak menunjukkan hasil yang signifikan dipengaruhi oleh variable-variabel seperti kadar HB dan BMI atlet. Hal ini ditunjukkan pada hasil perhitungan regresi multivariate memiliki angka signifikasi sebesar 0.2583 dan 0.2328 sehingga dapat diambil kesimpulan bahwa Ho gagal ditolak. (Gite et al., 2021) mengemukakan bahwa fleksibilitas dan BMI tidak berhubungan secara signifikan, namum BMI berhubungan dengan level aktivitas fis ik seseorang. Hal senada juga disampaikan oleh (Ding \& Jiang, 2020) bahwa aktivitas fisik berhubungan terbalik dengan BMI seseorang. Fleksibilitas atau kelenturan setiap atlet harus dilatih setiap hari agar terhindar dari cidera. Olahraga menari merupakan salah satu langkah untuk meningkatkan kelenturan dan juga kebugaran jasmani seseorang (Bastug, 2018).

Implikasi dari penelitian ini adalah bahwa kadar HB dan BMI atlet panahan sangat kecil dalam mempengaruhi kapasitas $\mathrm{VO}_{2}$ maks, namun demikian dengan memiliki kadar HB yang tinggi akan dapat menguntungkan atlet, sehingga hal itu 
Isti Dwi Puspita Wati ${ }^{1}$, A'yunin Sofro ${ }^{2}{ }^{\text {) }}$.Jp.jok (Jurnal Pendidikan. Jasmani, Olahraga dan Kesehatan). 5(1)

membuat atlet akan lebih cepat dalam proses recovery. Hal ini terjadi karena oksigen yang diperoleh di paru-paru akan cepat dapat didistribusikan ke seluruh tubuh. Bahwa kapasitas $\mathrm{VO}_{2}$ maks dan kelenturan merupakan hasil dari latihan yang secara terus menerus dilakukan dan ditingkatkan sehingga kadar HB dan BMI akan mengikuti pola latihan. Apabila tidak ada latihan maka kadar HB akan mengalami fluktuatif yang dapat mengganggu performa atlet demikian juga dengan BMI. Keterbatasan dalam penelitian ini adalah bahwa masih banyak faktor yang mempengaruhi kapasitas $\mathrm{VO}_{2}$ maks dan kelenturan dari atlet panahan yang berlum tercover sehingga harapannya aka nada penelitian lain yang dapat mengungkapkan fakta komponen apa saja yang mempengaruhi sehingga menjadi masukan bagi para pelatih untuk dapat meningkatkan komponen biomotor tersebut untuk dapat memperoleh kapasistas $\mathrm{VO}_{2}$ maks yang baik.

\section{SIMPULAN}

Berdasarkan hasil penelitian maka dapat diambil kesimpulan bahwa kapasitas $\mathrm{VO}_{2}$ maks dan kelenturan tidak dipengaruhi oleh kadar HB dan BMI atlet. Bahwa kadar HB dan BMI hanya mempengaruhi sekitar 36,189\% terhadap kapasitas VO2maks atlet, sedangkan terhadap kelenturan hanya sekitar 0,033\%. Hal ini menujukkan bahwa kadar HB dan BMI tidak berpengaruh signifikan terhadap VO2maks dan kelenturan atlet. Bahwa HB merupakan alat transportasi utama dalam membawa oksigen guna memenuhi kapasitas VO2maks. Namun tidak secara langsung mempengaruhi, demikian juga dengan kelenturan. Akan tetapi sebagai atlet maka kadar HB harus menjadi pertimbangan tersendiri karena berhubungan dengan recovery atlet. Semakin tinggi kadar HB maka recovery akan semakin cepat. Hal tersebut dapat menguntungkan atlet.

\section{DAFTAR RUJUKAN}

Aryaputra, A., Purwanto, B., \& Widodo, A. (2020). The Relationship Between Hemoglobin Concentration With Maksimum Oxygen Volume Levels In Obese Female. STRADA Jurnal Ilmiah Kesehatan, 9(2). https://doi.org/10.30994/sjik.v9i2.295

Baron, D. M., H.Hochrieser, M.Posch, Metnitz, Rhodes, R.P.Moreno, R.M.Pearse, \& P.Metnitz. (2014). Preoperative anaemia is associated with 
218 Isti Dwi Puspita Wati ${ }^{11}$, A'yunin Sofro ${ }^{2}{ }^{\text {}}$.Jp.jok (Jurnal Pendidikan. Jasmani, Olahraga dan Kesehatan). 5(1)

poor clinical outcome in non-cardiac surgery patients. British Journal of Anaesthesia, 113(4), 416-423. https://doi.org/https $: / /$ doi.org/10.1093/bja/aeu098

Bastug, G. (2018). Examination of Body Composition, Flexibility, Balance, and Concentration Related to Dance Exercise. Asian Journal of Education and Training , 4(3). https://doi.org/10.20448/journa1.522.2018.43.210.215

Brian Mackenzie. (2005). 101 Performance Evaluation Tests (B. Mackenzie (ed.)). Electric Word plc.

Ding, C., \& Jiang, Y. (2020). The relationship between body mass index and physical fitness among chinese university students: Results of a longitudinal study. Healthcare (Switzerland), 8(4). https://doi.org/10.3390/healthcare 8040570

Du Bois, A. M., Nelson, G. C., Ciccone, A. B., April, S. M., Thurston, T. S., Brown, L. E., Coburn, J. W., Galpin, A. J., \& Judelson, D. J. (2014). Effect Of Serial Apneas And Facial Immersion On High Intensity Aerobic Performance. Medicine \& Science in Sports \& Exercise, 46. https://doi.org/10.1249/01.mss.0000495581.06853.6c

Fernström, M., Fernberg, U., Eliason, G., \& Hurtig-Wennlöf, A. (2017). Aerobic fitness is associated with low cardiovascular disease risk: The impact of lifestyle on early risk factors for atherosclerosis in young healthy swedish individuals - the lifestyle, biomarker, and atherosclerosis study. Vascular Health and Risk Management. https://doi.org/10.2147/VHRM.S125966

Gite, A. A., Mukkamala, N., \& Parmar, L. (2021). Relationship between Body Mass Index and Flexibility in Young Adults. Journal of Pharmaceutical Research International. https://doi.org/10.9734/jpri/2021/v33i32a31723

Goodrich, J., Ryan, B., \& Byrnes, W. (2018). The Influence of Oxygen Saturation on the Relationship Between Hemoglobin Mass and VO2maks. Sports Medicine International Open, 02(04). https://doi.org/10.1055/a-0655-7207

Jacobs, R. A., Rasmussen, P., Siebenmann, C., Díaz, V., Gassmann, M., Pesta, D., Gnaiger, E., Nordsborg, N. B., Robach, P., \& Lundby, C. (2011). Determinants of time trial performance and maksimal incremental exercise in highly trained endurance athletes. Journal of Applied Physiology, 111(5), 1422-1430. https://doi.org/10.1152/japplphysiol.00625.2011

Joyner, M. J., \& Lundby, C. (2018). Concepts about VO2maks and Trainability Are Context Dependent. Exercise and Sport Sciences Reviews, 46(3), 138143. https://doi.org/10.1249/JES.0000000000000150

Kuncoro, W. P., Sugiharto, S., \& Kinanti, R. G. (2020). Hubungan Antara Volume Oksigen Maksimal (O2 Maks) Dengan Heart Rate Maksimal (Hr 
Isti Dwi Puspita Wati ${ }^{1}$, A'yunin Sofro ${ }^{2}{ }^{\text {) }}$.Jp.jok (Jurnal Pendidikan. Jasmani, Olahraga dan Kesehatan). 5(1)

Maks) Pada Mahasiswa Jurusan Ilmu Keolahragaan. Jurnal Sport Science. https://doi.org/10.17977/um057v 10i1p32-41

Malczewska-Lenczowska, J., Orysiak, J., Majorczyk, E., Zdanowicz, R., Szczepańska, B., Starczewski, M., Kaczmarski, J., Dybek, T., Pokrywka, A., Ahmetov, I. I., \& Sitkowski, D. (2016). Total hemoglobin mass, aerobic capacity, and hbb gene in polish road cyclists. Journal of Strength and $\begin{array}{ll}\text { Conditioning } \quad \text { Research, } & \text { 30(12). }\end{array}$ https://doi.org/10.1519/JSC.0000000000001435

Neya, M., Enoki, T., Ohiwa, N., Kawahara, T., \& Gore, C. J. (2012). Ten Hours Nightly Simulated Altitude at $3000 \mathrm{~m}$ Increases Hemoglobin Mass and VO2maks. Int J Sports Physiol Perform.

Sugiyono. (2017). Metode Penelitian Kuantitatif, Kualitatif, dan R\&D. Bandung : Alfabeta, CV

Wehrlin, J. P., Marti, B., \& Hallén, J. (2016). Hemoglobin mass and aerobic performance at moderate altitude in elite athletes. In Advances in Experimental Medicine and Biology (Vol. 903). https://doi.org/10.1007/9781-4899-7678-9_24 